\title{
SERVICE ORIENTATION OF THE EMPLOYEES IN SERBIA'S TOURISM AGENCIES
}

\author{
Milos Marjanovic* \\ Faculty of Sciences, University of Novi Sad, Novi Sad, The Republic of Serbia
}

In a time of fierce competition in the tourist services market, it is very important to pay attention to businesses' service orientation towards end users. Service orientation can be considered as a competitive advantage on the demanding tourism market. In this study, the relationship between service orientation, job satisfaction and empowerment among the employees of Serbian travel agencies is examined. A survey was conducted through an online questionnaire. The survey included a total of 94 respondents. The study is aimed at investigating the connection between employee service orientation, job satisfaction and empowerment. The paper also investigates whether there are significant differences between the measured variables among the employees with and without tourism education. The results showed that job satisfaction had a significant impact on service orientation. The impact of empowerment on service orientation proved to be a less significant statistical variable. According to the research study, job satisfaction occurs as a mediator between empowerment and service orientation. Also, there is no statistically significant relationship between the measured variables and tourism-related education.

Keywords: service orientation, job satisfaction, empowerment, travel agencies, tourism education, prosocial service behavior

JEL Classification: L83

\section{INTRODUCTION}

The human potential is companies' core strength in the business world, where there is great competitiveness. Tourism employees play a significant role when the provision of quality services and problem solving are concerned, especially so when the customer is dissatisfied. Given the fact that employees are in direct contact with clients, their behavior directly affects

* Correspondence to: M. Marjanovic, Faculty of sciences, University of Novi Sad, Trg Dositeja Obradovića 3, 21102 Novi Sad, the Republic of Serbia; e-mail:milos.marjanovic@mail.com clients' decision-making process, as well as clients' perception of the quality of the services provided (Malhotra \& Mukherjee, 2004). Service orientation is a very important element of an organization responsible for the creation of the conditions that encourage employees to work and, in turn, provide high-quality services. Employee service orientation can be a major factor of competitiveness on the market. A serviceorientated employee is an important actor who makes a difference between competitors. Employees play the major role when speaking about the provision of quality services and problem solving. They are in direct contact with clients, constantly interacting with 
them. Their behavior influences clients' perceptions of the quality of the services provided, as well as clients' decision-making regarding their potential new visit to the same organization or purchase of the same product (Malhotra \& Mukherjee, 2004). R. Deshpandé, J. U. Farley and Jr. F. Webster (1993) point out the fact that service-oriented employees put their customers in the first place, and then all other stakeholders (managers, owners) come, in order to develop profitable businesses and ensure longterm success. Many researchers have had a focus on service orientation. Many of them have come to the conclusion that there is a positive relationship between customer satisfaction and loyalty, and between customer satisfaction and their aspirations to recommending suppliers to other customers as well (Hartline \& Jones, 1996). Creating a loyal customer is one of the main goals of travel agencies. A loyal customer stems from the service orientation of the service employee. Therefore, it is very important that the company management should constantly be working on the identification of the conditions that affect each individual in order to be service-oriented and contribute to the positive business of the company (Lee, Nam, Park \& Lee, 2006). Service orientation is one of the key factors when creating a superior value for the customer. Many research studies have shown that customer satisfaction, loyalty, an increase in the profit and the growth of the organization are directly the result of the company's service orientation. On the other hand, a lack of initiative to establish a service orientation policy, and a lack of the measurement and management of employee service orientation, may reduce long-term organizational performance (Lytle, Hom \& Mokwa, 1998).

Service orientation can be defined as an employees' additional effort directed towards the organization itself or towards its customers (Bettencourt \& Brown, 1997). A lot of research has addressed the precondition for service orientation. Work satisfaction (Netemeyer, Boles, McKee \& McMurrian, 1997), empowerment (Spreitzer, 1995; Lytle et al, 1998), training (Lux, Jex \& Hansen, 1996), as well as the reward system (Lytle et $a l, 1998)$ have a great influence on employee service orientation.

The subject matter of the research study carried out in this paper is the level of job satisfaction, service orientation and empowerment in Serbian travel agencies. The aim of this study is to formulate and empirically test an integrated model of interrelationships and impacts between service orientation, job satisfaction, and empowerment. The author made several hypotheses on this basis that will be tested. A survey questionnaire, distributed online, was used to collect the data. The target group is the employees of Serbian travel agencies, regardless of their position in the company. The paper consists of several sections. The topic, subject matter and objectives of the research study are presented in the Introduction. After that, a review of other authors' research studies on service orientation, job satisfaction, empowerment and education is given through a review of the consulted literature, which is followed by the section in which the used methods and the discussion of the obtained results are outlined. The Conclusion provides considerations about the topic of this paper.

\section{SERVICE ORIENTATION}

The concept of Service Orientation (SO) can be viewed at two levels. The first level is the organizational level, and the second is the individual level. The organizational level of orientation is directed towards what the management of the organization consider to be significant when delivering a high quality. The individual level of orientation refers to the service orientation of the employee him-/herself, which, in his/her opinion, is important for the delivery of high-quality services (Saura, Contrí, Taulet \& Velázquez, 2005). An approach like this is discussed in this paper. One of the most important factors that influence the quality of the service provided in the service industry is the service orientation of employees (Petrović \& Marković, 2012). Employee service orientation plays the key role in the perception of the quality of a service and the level of customer satisfaction (Sergeant \& Frenkel, 2000). Working in tourism, or working in travel agencies, requires a high level of interaction with consumers. Therefore, understanding the concept of service orientation should play an important role in service businesses. In the literature, beside employee service orientation, there is also the term "service orientation of the 
organization", which can be defined as the overall climate of the organization or as the perceptions, beliefs and opinions of all of its employees (Lytle et al, 1998).

There is no unique definition of service orientation. Numerous theorists have given their definitions of service orientation. Some authors define it as employees' desire to meet their clients' needs (Brown, Mowen, Donava \& Licata, 2002), or employees' desire to serve their clients in a useful, cooperative and kind manner. Many studies have confirmed the fact that the availability and courtesy of staff are more important to guests than the organization's expertise and technique (Dienhart, Gregoire, Downey \& Knight, 1992). Service orientation can be viewed as a business resource (Zablah, Franke, Brown \& Bartholomew, 2012). Service-oriented employees will not only provide the service within the scope of their competences, but they will also endeavor to provide an additional quality (e.g. inform the client about additional content at the destination, propose an arrangement in accordance with the price/quality ratio, bring some personal or other experiences from the destination, indicate the disadvantages of the arrangement). This behavior will certainly have a positive impact on the client, and the client will feel that he/she has received an "extra" service. Clients will feel closeness with the employee and the agency, which will affect his/her perception of the quality of the service (Lee, Park \& Park, 1997). Perceived service orientation of customer contact service employees in the firms: The structural relationship between organizational values and employees's attitudes. Many research studies indicate that kindness, accessibility and open communication with employees are more important to the client than their competences and work organization (Čerović, Raičević, Todosijević and Tomka, 2002).

\section{JOB SATISFACTION}

A large number of theorists believe that Job Satisfaction (JS) can strongly affect the overall business of a company. Job satisfaction is a strong indicator of the good business performance and well-being of the organization. This further implies that the employees who are satisfied rarely leave the collective. Job satisfaction is one of the most researched phenomena in the field of management. A large number of authors have done research in the elements that influence job satisfaction. A high level of job satisfaction has proven to lead to increased performance and commitment to work, whereas a low level of job satisfaction may cause a decrease in motivation (Locke, 1976; Brown \& Peterson, 1993). There are numerous definitions of job satisfaction, most often mentioned by E. A. Locke (1976), who says that job satisfaction is a positive emotional reaction of an employee, which comes from his/her work responsibilities or experience. Job satisfaction can be defined as an employee's positive or negative feelings about their job (Odom, Boxx \& Dunn, 1990). M. Hartline and O. Ferrell (1996) say that job satisfaction in an organization is very important, because it affects the quality of the provided service.

The manager's main task is to constantly maintain and increase job satisfaction of his/her employees in order to achieve positive business results, on the one hand, and to constantly have satisfied clients, on the other (Rogers, Clow \& Kash, 1994). Job satisfaction has an impact on employee loyalty (Williams \& Hazer, 1986) and service orientation (Hoffman \& Ingram, 1992). Some authors have shown that job satisfaction has a positive effect on job performance (Birnbaum \& Sommers, 1993). The more satisfied the worker is, the more he/she will strive for their performance.

Therefore, the first hypothesis states:

H1: Job satisfaction has a positive impact on service orientation.

\section{EMPOWERMENT}

Organizational support, i.e. Empowerment (EM), can be defined as the degree of the support and understanding a person receives from his/her superior. The focus is on the leader who gives guidance to his/her employees, treats them with respect, and considers their contribution to the organization's operations worthwhile (Netemeyer, Boles, McKee \& McMurrian, 1997). Some authors define empowerment as allowing employees to 
make their own decisions in the day-to-day service of clients. Empowerment is very important for the provision of the services that are heterogeneous and need to be tailored to customers' requirements. In this case, the employee has a complete freedom to tailor the service to clients' needs (Jha \& Nair, 2008). R. Brymer (1991) believes that empowerment implies a manager's willingness to give more freedom to his/her employees in the workplace. A good leader supports employees by facilitating their path to their goals, thereby increasing their job satisfaction, all with the aim of increasing productivity and achieving the goals of the company (Brown \& Peterson, 1993). Some authors have put the leader at the forefront of organizational support (Webster, 1988). Since tourism is a service activity, and employees are often in contact with clients, empowerment is necessary, because employees need to solve all problems in order to satisfy the customer (Hartline \& Ferrel, 1996). B. Shimko (1994) states that empowerment can be manifested as the freedom of employees to bypass standard work procedures, all with the aim of meeting clients' needs.

Organizational support has multiple effects. Empowerment increases an employee's self-esteem and increases his/her loyalty to the organization (Lee, Park \& Park, 1997), as well as his/her job satisfaction (Spreitzer, Kizilos \& Nason, 1997). In addition to the fact that organizational support affects job satisfaction and employee loyalty, it also affects employees' work performance (Lee et al, 2006).

Therefore, the additional hypotheses are:

$\mathrm{H} 2$ : The organizational support has a positive effect on job satisfaction.

H3: The organizational support has a direct impact on service orientation.

\section{EDUCATION}

Qualified human resources are of great importance for the productivity of a company. This is especially significant insofar as their education is related to the area of the business conducted by the company. P. Barron (2008) states that education in the service sector, and above all in tourism, is one of the factors that will play a crucial role in the future when the quality of the service provided is concerned. It is very difficult to find and retain the highly-skilled workers in the service industry who will be able to provide high-quality services to the current and future clients. Therefore, education plays a very important role in the future development of this service sector. V. Stefanović and Ž. Gligorijević (2010) state that education in tourism is very important, because there is no continuous economic prosperity without continuous education. Employee education may have quite a big impact on employee satisfaction. A. Lillo, A. Ramon and M. Sevilla (2007) state that the amount of the knowledge and skills that each individual possesses are the major elements of human capital. The same authors state that an individual's competences depend on the level of investment in formal education and the strengthening of practical knowledge through work experience.

The paper will examine whether there are statistically significant differences in the job satisfaction degree and the attitudes towards organizational support and service orientation between the employees who have tourism education and those who do not. In this context, the hypothesis $\mathrm{H} 4$ can be formulated as follows:

H4: There is a difference in the job satisfaction degree and the attitudes towards empowerment and service orientation between the employees who have tourism education and those who do not.

\section{METHODOLOGY}

The data for this research study were collected from the employed in Serbian travel agencies. The database of the travel agency Euroturs was used for the submission of this questionnaire. The questionnaire was distributed by means of software for communication with partners. The questionnaire was forwarded to tour operators and subagents. The questionnaire was sent to a total of 380 e-mail addresses, and a total of 94 respondents participated in the survey. 
Quantitative measurement was performed in order to cover the assertions related to job satisfaction, employee service orientation, and empowerment through a structural questionnaire. A Likert scale consisting of the five agreement levels was used for this questionnaire, in which 1 means "Disagree at all", 2 means "Disagree", 3 means "No opinion" 4 means "Agree", and 5 means "Strongly agree".

The variables used to measure job satisfaction were adapted from the research done by W. G. Kim et al (2005). The questionnaire from the research done by R. Dienhart et al (1992) and W. G. Kim, J. K. Leonga and Y. K. Lee (2005) was adapted in order to measure service orientation. Empowerment was measured by the questionnaire constructed by G. Spreitzer (1995) and adapted from his research study. An analysis of the papers that addressed these variables preceded the creation of this questionnaire.

The questionnaire consists of four parts. The first part covers the variables related to the sociodemographic characteristics of the respondents (i.e. the gender, age, the level of education, etc.). Job satisfaction was measured in the second part, whereas in the third part, the questions were about service orientation. In the fourth part, organizational support was measured.

The data analysis was performed by using the SPSS 25.0 statistical software. Descriptive statistics, regression analysis, and an independent T-test were used for the analysis. Descriptive statistics were applied when presenting the sociodemographic characteristics of the respondents. Regression analysis was applied so as to predict the impact of the independent variables of job satisfaction and organizational support on service orientation. The T-test for the two independent samples measured a potential difference between the gender and tourismrelated education. The Cronbach's alpha test was used to test the reliability (internal consistency) of each measuring instrument in the questionnaire, i.e. the group of the questions used to evaluate the same dimension (in this case, JS, SO, EM).

\section{RESULTS}

Analyzing the data, it was found that a much higher percentage of participation accounted for women
$(80.85 \%)$ and less than one-fifth of the respondents were men (only 19.15\%). About one-third of the respondents were in their thirties, while $30.83 \%$ of the respondents were under 31 years of age. Regarding the respondents' level of education, a total of $19.15 \%$ of them were with a high-school diploma, $58.51 \%$ had higher education, and $22.34 \%$ had a master's degree. A total of $65.96 \%$ of the respondents had tourismrelated education. Among the survey participants, $35.11 \%$ of them had an experience in tourism lasting up to 5 years, and $21.27 \%$ of the respondents had over 20 years of experience in tourism (Table 1).

Table 1 The respondents' sociodemographic characteristics

\begin{tabular}{|c|c|c|}
\hline Variables & Number & Percent \% \\
\hline \multicolumn{3}{|l|}{ Gender } \\
\hline Male & 18 & 19.15 \\
\hline Female & 76 & 80.85 \\
\hline \multicolumn{3}{|l|}{ Age } \\
\hline 20 and under 20 & 3 & 3.18 \\
\hline from 21 to 30 & 26 & 27.65 \\
\hline from 31 to 40 & 31 & 32.97 \\
\hline from 41 to 50 & 17 & 18.10 \\
\hline 51 and over & 17 & 18.10 \\
\hline \multicolumn{3}{|l|}{ Education level } \\
\hline High school & 18 & 19.15 \\
\hline College of applied studies & 55 & 58.51 \\
\hline Master's & 21 & 22.34 \\
\hline \multicolumn{3}{|l|}{ Education related to tourism } \\
\hline Yes & 62 & 65.96 \\
\hline No & 32 & 34.04 \\
\hline \multicolumn{3}{|l|}{ Years of work experience } \\
\hline from 1 to 5 & 33 & 35.11 \\
\hline from 6 to 10 & 18 & 19.15 \\
\hline from 11 to 20 & 23 & 24.47 \\
\hline 20 and more & 20 & 21.27 \\
\hline
\end{tabular}

Source: Author 
Table 2 shows the mean, the standard deviation, and the correlation coefficient for all the three measured variables. It can be seen that service orientation and job satisfaction have a stronger degree of linear dependence $(r=0.618)$ than the moderate degree of linear dependence between job satisfaction and organizational support $(\mathrm{r}=0.498)$, and service orientation and organizational support $(\mathrm{r}=0.437)$.

The obtained results show a high level of statistical significance, which means that a high level of empowerment is accompanied by a high level of job satisfaction. A simple linear regression tests the impact of empowerment on job satisfaction (Table 3). The results show that there is a statistically significant influence (sig $=0.000$ ) and that the influence is as follows:

$$
J S=1.712+0.567 * E M
$$

This prediction model explains $20.8 \%\left(\mathrm{R}^{2}=0.208\right)$ of the variance of job satisfaction.

The results indicate that job satisfaction has a significant impact on service orientation and that the introduction of this variable in the regression model renders that the influence of empowerment is insignificant. This means that job satisfaction is a mediator between service orientation and empowerment.

Simple linear regression tests the impact of empowerment on service orientation. The results show that there is a statistically significant influence $(\operatorname{sig}=0.000)$ and that the influence is as follows:

$$
S O=2.547+0.431 * E M
$$

\begin{tabular}{|c|c|c|c|c|c|c|c|}
\hline Variable & $\begin{array}{c}\text { Cronbach's } \\
\text { alpha }\end{array}$ & Questions & Mean & St. dev. & $\begin{array}{l}\text { Correlation } \\
\text { coefficient }\end{array}$ & & \\
\hline $\begin{array}{l}\text { Job } \\
\text { satisfaction }\end{array}$ & .906 & 7 & 3.87 & .74117 & $\begin{array}{c}\text { Job } \\
\text { satisfaction }\end{array}$ & $\begin{array}{c}\text { Service } \\
\text { orientation }\end{array}$ & Empowerment \\
\hline $\begin{array}{l}\text { Service } \\
\text { orientation }\end{array}$ & 696 & 3 & 4.19 & .65529 & $.618^{* *}$ & & \\
\hline Empowerment & .711 & 6 & 3.81 & .59704 & $.498^{* *}$ & $.437^{* *}$ & \\
\hline
\end{tabular}

Table 2 Cronbach's alphas, the mean, the standard deviation and the correlation coefficient

Note: ${ }^{* *}$ The correlation is significant at the 0.01 level.

Source: Author

\begin{tabular}{|c|c|c|c|c|c|c|c|}
\hline \multirow{2}{*}{ Model } & \multicolumn{2}{|c|}{ Unstandardized coefficient } & \multirow{2}{*}{$\begin{array}{c}\text { Standardized } \\
\text { coefficient } \\
\text { Beta } \\
\end{array}$} & \multirow{2}{*}{$\mathrm{t}$} & \multirow{2}{*}{ Significance } & \multirow{2}{*}{$\mathrm{R}^{2}$} & \multirow{2}{*}{$\begin{array}{l}\text { sig. } R^{2} \\
\text { change }\end{array}$} \\
\hline & B & Std. error & & & & & \\
\hline 1 (constant) & 2.547 & .416 & \multirow{2}{*}{.393} & 6.129 & .000 & \multirow{2}{*}{.154} & \multirow{2}{*}{0.000} \\
\hline EM & .431 & .108 & & 4.007 & .000 & & \\
\hline 2 (constant) & 1.741 & .386 & & $4 \cdot 511$ & .000 & \multirow{3}{*}{.379} & \multirow{3}{*}{0.000} \\
\hline EM & .164 & .104 & .150 & 1.575 & .119 & & \\
\hline JS & .471 & .084 & .533 & 5.611 & .000 & & \\
\hline
\end{tabular}

Table 3 The impact of empowerment, job satisfaction and service orientation

a. The dependent variable SO

Source: Author 
This prediction model explains $15.4 \%\left(\mathrm{R}^{2}=0.154\right)$ of the service orientation variance.

Multiple linear regression tests the impact of empowerment and job satisfaction on service orientation. The results show that there is a statistically significant influence $(\operatorname{sig}=0.000)$ and that the influence is as follows:

$$
S O=1.741+0.164 * E M+0.471 * J S
$$

This prediction model explains $37.9 \%\left(\mathrm{R}^{2}=0.379\right)$ of the service orientation variance. Compared to the first model, the second introduces a significant improvement (sig. $\mathrm{R}^{2}$ change $=0.000$ ). In the second model, job satisfaction is a predictor with statistically significant predictive power. Unlike in the first model, empowerment is no longer a predictor with statistically significant predictive power in the second model. This indicates the correlation between the two predictors, as was confirmed earlier.

In Table 4, it can be seen that the T-test of the independent samples compares the results of service orientation, job satisfaction and empowerment for the employees with tourism education and those with a different educational background. The results show that there is no significant statistical difference between the groups with tourism education $(\mathrm{M}=3.81$, $\mathrm{M} 1=4.14, \mathrm{M} 2=3.81)$, and those without it $(\mathrm{M}=3.99$, $\mathrm{M} 1=4.27, \mathrm{M} 2=3.82$ ).

In Table 5, the T-test of the independent variables shows how the measured variables manifest in the male and female populations. The obtained results show that there is no statistically significant difference between the male and female respondents.

\section{DISCUSSION}

This study is aimed at formulating and empirically testing an integrated model of interrelationships and impacts between service orientation, job satisfaction, and empowerment. This was achieved through an analysis of the adequate literature and statistical data processing. The results of the analysis show that job satisfaction has a positive effect on service orientation, thus confirming the hypothesis H1. This confirms the author's assertion that there is a positive relationship between job satisfaction and employee service orientation. K. Hoffman and T. Ingram (1992) describe the sense of satisfaction in the workplace as a result of kindness, sensitivity, concern for the needs of others, understanding, and many other character

Table 4 The comparison of the measured variables by tourism education

\begin{tabular}{c|cccccc}
\hline \multirow{2}{*}{$\begin{array}{c}\text { Tourism } \\
\text { education }\end{array}$} & \multicolumn{2}{|c}{ Job satisfaction } & \multicolumn{2}{c}{ Service orientation } & \multicolumn{2}{c}{ Empowerment } \\
& Mean $(M)$ & $\mathrm{p}$ & Mean $(\mathrm{M} 1)$ & $\mathrm{p}$ & Mean $(\mathrm{M} 2)$ & $\mathrm{p}$ \\
\hline YES & 3.81 & .284 & 4.14 & \multirow{2}{*}{.364} & 3.81 & .897 \\
NO & 3.99 & & 4.27 & & 3.82 & \\
\hline
\end{tabular}

The T-test is significant at the * $p<0.05,{ }^{* *} p<0.01, * * *$ and $p<0.001$.

Source: Author

Table 5 The comparison of the measured variables by the gender

\begin{tabular}{c|cccccc}
\hline \multirow{2}{*}{ Gender } & \multicolumn{2}{|c}{ Job satisfaction } & \multicolumn{2}{c}{ Service orientation } & \multicolumn{2}{c}{ Empowerment } \\
& Mean $(M)$ & $p$ & Mean $(M 1)$ & $p$ & Mean $($ M2) & $p$ \\
\hline Male & 4.01 & .397 & 4.31 & \multirow{2}{*}{.923} & 3.96 & .263 \\
Female & 3.84 & .39 & 4.16 & & 3.78 & \\
\hline
\end{tabular}

The T-test is significant at * $p<0.05,{ }^{* *} p<0.01,{ }^{* * *}$ and $p<0.001$.

Source: Author 
traits that are believed to be inherent in the serviceoriented staff. Job satisfaction also affects employees' maximum respect for customers, especially so in the service sector. Accordingly, researchers point out the fact that job satisfaction has a positive impact on service orientation. A high level of job satisfaction is accompanied by a high level of service orientation. Therefore, the main task of the company manager is to achieve and maintain a high level of job satisfaction in his/her collective, which further leads to positive economic results, which is the basic goal of every company's existence.

Further results show that empowerment, i.e. support from superiors, positively influences job satisfaction, which is in line with the study by G. Spreitzer et al (1997). This confirms the author's assertion in the hypothesis H2. Organizational support leads to an increase in employees' self-esteem, which further affects their job satisfaction. A satisfied employee will maximize his/her ability to reach or exceed customer requirements in the service delivery process. Empowerment can influence the creativity and imagination of tourism workers when creating tourist products, based on direct sales experience. When service orientation is inserted into the research model, it is possible to conclude that the impact of organizational support is not significant for employee service orientation, thus rejecting assertion in the hypothesis $\mathrm{H} 3$, which says that empowerment has a direct impact on service orientation. Here, the role of the mediator is assigned to job satisfaction, which leads to the conclusion that organizational support does not have a direct impact on service orientation.

Given the fact that ever-increasing attention is being paid to worker education today, the link between employees with tourism education and those without it was examined. The research shows that there are no statistically significant differences between employees with tourism-related education and those whose education is not tourism-related; those differences are random instead. This rejects the author's assertion expressed in the hypothesis $\mathrm{H} 4$ that there is a difference in the measured parameters among the respondents with tourism education and those without it. Certainly, continuous education is needed, because the market in which travel agencies operate is heterogeneous, services are not standardized and demand constantly changes. Trained managers can anticipate changes in the market and adapt business policies to contemporary trends. In the last two decades, an ever-greater number of tourism schools have intensively been opened in Serbia, so that educated staff will be available to companies, which further implies an easier achievement of a business policy. The attitudes of the male and female populations towards service orientation, job satisfaction and empowerment were also compared. The result obtained indicates that there is no statistically significant relationship and that the differences are of random nature. It is a fact that a significantly larger number of women work in the tourism industry, but the number of male workers is increasing, given the fact that this sector is becoming increasingly demanding.

\section{CONCLUSION}

In this paper, an attempt was made to expand the knowledge of employee service orientation, organizational support and job satisfaction in Serbian travel agencies. The mutual influence of these three variables was tested. The hypotheses set by the author were either confirmed or rejected with the help of statistical data processing. The results show that job satisfaction has a significant impact on service orientation. If an employee is not fully satisfied with his/her job, he/she is unable to provide a high-quality service. On the other hand, when empowerment is introduced into the model, it can be concluded that it indirectly affects employee service orientation. The impact of organizational support on service orientation is felt through job satisfaction. This means that job satisfaction is the mediator between organizational support and service orientation. This study also highlights the importance of continuous employee education. Tourism is a service industry in which demand rapidly changes and trends need to be constantly monitored so as to keep up with the competition. 
The results of this research study may be useful for managers in travel agencies because, based on employees' behavior and attitudes, they can improve service standards. As the support of superiors affects job satisfaction, the role of managers would be to strive to create a comfortable working atmosphere in the organization and have an open relationship with their employees. An effective system for measuring the performance of a company's employees provides an opportunity for executives to align performance with the company's strategy. Every company is a heterogeneous system requiring a unique model for creating a work environment in which service orientation will be in the forefront. It is necessary to find a way to motivate individuals to provide the highest-quality services (Domanovic, 2013). Precisely, this is the mission of every service-oriented company.

By analyzing all of the foregoing, we can see that this paper has certain limitations that may serve as an idea for some future research. The survey was conducted at Serbian travel agencies. The survey included tour-operator travel agencies and travel agencies brokers for sale arrangements (subagents). Future research could address a specific type of agency, i.e. research could be conducted so as to only cover tour operators or subagents, since there are significant differences between the two types of travel agencies. The results of the tested categories for both types of travel agencies could also be compared. Another limitation is that all employees of the given agencies participated in the survey, regardless of their position in the company (sales, commercial, guides. Future research could be conducted by taking into consideration the job positions that would identify significant differences between the positions that are in constant contact with customers (the sales service, travel guides and escorts) and the positions that are not often in contact with customers (product creation services). Another limitation lies in the fact that the research study was conducted at agencies in the territory of Serbia. Future research could address the testing of the same variables in the neighboring countries or on tourism-leading markets, after which the findings of such research would be compared. In this paper, only three categories were tested (service orientation, job satisfaction and organizational support). Future research could be based on how the reward system affects job satisfaction and loyalty to the company, or how job satisfaction reflects in the provision of "extra" customer service, or yet how internal communication affects service orientation.

\section{REFERENCE}

Barron, P. (2008). Education and talent management: Implications for the hospitality industry. International Journal of Contemporary Hospitality Management, 20(7), 730742. doi:10.1108/09596110810897583

Bettencourt, A., \& Brown, W. (1997). Contact employees: Relationship among workplace fairness, job satisfaction and prosocial service behavior. Journal of Retailing, 73(1), 3961. doi.org/10.1016/S0022-4359(97)90014-2

Birnbaum, D., \& Somers, M. (1993). Fitting job performance into turnover model: An examination of the form of the job performance - turnover relationship and path model. Journal of Management, 19(1), 1-11. doi.org/10.1016/01492063(93)90041-K

Brown, P., \& Peterson, A. (1993). Antecendents and consequences of salesperson job satisfaction: Meta-analysis and assessment of casual effects. Journal of Marketing Research, 30(1), 63-77. doi.org/10.1177/002224379303000106

Brown, J., Mowen, C., Donava, T., \& Licata, W. (2002). The customer orientation of service workers: Personality trait effects on self and supervisor performance ratings. Journal of Marketing Research, 39(1), 110-119. doi.org/10.1509/ jmkr.39.1.110.18928

Brymer, R. (1991). Employee empowerment: A guest-driven leadership strategy. Cornell Hospitality Quarterly, 32(1), 5868. doi :10.1177/001088049103200116

Čerović, S., Raičević, B., Todosijević, B. i Tomka, D. (2002). Strategijski menadžment turističke priorede Srbije. Beograd, RS; Želnik.

Deshpandé, R., Farley, J. U., \& Webster, Jr. F. (1993). Corporate culture, customer orientation, and innovativeness in Japanese firms: A quadrate analysis. Journal of Marketing, 57(1), 23-37. doi:10.2307/1252055 
Dienhart, R., Gregoire, B., Downey, G., \& Knight, K. (1992). Service orientation of restaurant employees. International Journal of Hospitality Management, 11(4), 331-346. doi. org/10.1016/0278-4319(92)90050-6

Domanovic, V. (2013). The effectiveness of the performance measurement in terms of contemporary business environment. Economic Horizons, 15(1), 33-46. doi:10.5937/ ekonhor1301031D

Hartline, M., \& Farrell, O. (1996). The management of customercontact service employees: An empirical investigation. Journal of Marketing, 60(4), 52-70. doi:10.2307/1251901

Hartline, M., \& Jones, K. (1996). Employee performance cues in a hotel service environment: Influence on perceived service quality, value, and word-of-mouth intentions. Journal of Business Research, 35(3), 207-215. doi.org/10.1016/01482963(95)00126-3

Hoffman, K., \& Ingram, T. (1992). Service provider job satisfaction and customer oriented performance. The Journal of Service Marketing, 6(2), 68-78. doi. org/10.1108/08876049210035872

Jha, S., \& Nair, S. (2008). Influence of locus of control, job characteristics and superior-Subordinate relationship on psychological empowerment. Journal of Management Research, 8(3), 147-161.

Kim, W. G., Leonga, J. K., \& Lee, Y. K. (2005). Effect of service orientation on job satisfaction, organizational commitment, and intention of leaving in a casual dining chain restaurant. International Journal of Hospitality Management, 24(2), 171-193. doi:10.1016/j.ijhm.2004.05.004

Lee, Y., Park, D., \& Park, Y. (1997). Perceived service orientation of customer contact service employees in the firms: The structural relationship between organizational values and employees"s attitudes. Asia Pacific Journal of Tourism Research, 4(1), 59-70.

Lee, Y., Nam, J., Park, D., \& Lee, K. (2006). What factors influence customer-oriented prosocial behavior of customer-contact employees? Journal of Service Marketing, 20(4), 251-264. doi:10.1108/08876040610674599

Lillo, A., Ramon, A., \& Sevilla, M. (2007). El capital humano como factor estrategico para la competitividad del sector turistico. Cuadernos de Turismo, 19, 47-69.
Locke, E. A. (1976). The nature and causes of job satisfaction. In M. D. Dunnette, (Ed.). Handbook of industrial and organizational psychology (pp. 1297-1343). Chicago, IL: Rand McNally.

Lux, D., Jex, S., \& Hansen, C. (1996). Factors influencing employee perceptions of customer service climate. Journal of market - focused management, 1(1), 65-86. doi:10.1007/ bf00129604

Lytle, S., Hom, W., \& Mokwa, P. (1998). SERV*OR: A managerial measure of organizational service-orientation. Journal of Retailing, 74(4), 455-489. doi.org/10.1016/S00224359(99)80104-3

Malhotra, N., \& Mukherjee, A. (2004). The relative influence of organizational commitment and job satisfaction on service quality of customer-contact employees in banking call centers. Journal of Service Marketing, 18(3), 162-174. doi:10.1108/08876040410536477

Netemeyer, G., Boles, S., McKee, O., \& McMurrian, R. (1997). An investigation into the antecendents of organizational citizenship behaviors in a personal selling context. Journal of Marketing, 61(3), 85-98. doi.org/10.2307/1251791

Odom, R., Boxx, W., \& Dunn, M. (1990). Organizational culture, commitment, satisfaction and cohesion. Public Productivity and Management Review, 14(2), 157-168. doi:10.2307/3380963

Petrović, D., \& Marković, J. (2012). Researching connection between service orientation and work satisfaction: A study of hotel employee. Turizam, 16(1), 29-39.

Rogers, J., Clow, K., \& Kash, T. (1994). Increasing job satisfaction of service personnel. Journal of Service Marketing, 8(1), 14-26. doi.org/10.1108/08876049410053267

Saura, I. G., Contrí, G. B., Taulet, A. C., \& Velázquez, B. M. (2005). Relationships among customer orientation, service orientation and job satisfaction in financial services. International Journal of Service Industry Management, 16(5), 497-525. doi:10.1108/09564230510625787

Sergeant, A., \& Frenkel, S. (2000). When do customer contact employees satisfy customers? Journal of Service Research, 3(1), 18-34. doi.org/10.1177/109467050031002

Shimko, B. (1994). Breaking the rules for better service. The Cornell Hotel and Restaurant Administration Quarterly, 35(4), 18-22. doi.org/10.1177/001088049403500416 
Spreitzer, G. (1995). Psychological empowerment in the workplace: Dimensions, measurement, and validation. Academy of Management Journal, 38(5), 1442-1465. doi. org $/ 10.5465 / 256865$

Spreitzer, G., Kizilos, M., \& Nason, S. (1997). A dimensional analysis of the relationsheep between psychological empowerment and effectiveness, satisfaction, and strain. Journal of Management, 23(5), 679-704. doi. org/10.1177/014920639702300504

Stefanović, V. i Gligorijević, Ž. (2010). Ekonomika turizma. Niš, RS: SVEN.

Webster, F. (1988). The rediscovery of the marketing concept. Busines Horisons, 31(3), 29-39. doi.org/10.1016/00076813(88)90006-7
Williams, L., \& Hazer, J. (1986). Antecendents and consequences of satisfaction and commitment in turnover models: A reanalysis using latent variable structural equation methods. Journal of Applied Psyhology, 71(2), 219231. doi.org/10.1037/0021-9010.71.2.219

Zablah, R., Franke, R., Brown, J., \& Bartholomew, E. (2012). How and when does customer orientation influence frontline employee job outcomes? A meta-analityc evaluation. Journal of Marketing, 76(3), 21-40. doi.org/10.1509/ jm.10.0231

\section{Received on $24^{\text {th }}$ September 2019, after revision, accepted for publication on $13^{\text {th }}$ April 2020 \\ Published online on $24^{\text {th }}$ April 2020}

Milos Marjanovic is a PhD student at the Faculty of Sciences and Mathematics, University of Novi Sad, in the field of geoscience (tourism). His area of interest is his motivation in tourism, geotourism, regional geography. 


\title{
USLUŽNA ORIJENTACIJA ZAPOSLENIH U TURISTIČKIM AGENCIJAMA U REPUBLICI SRBIJI
}

\author{
Miloš Marjanović* \\ Prirodno-matematički fakultet, Univerzitet u Novom Sadu
}

U vremenu surove konkurencije na tržištu pružanja turističkih usluga, bitno je obratiti pažnju na uslužnu orijentisanost preduzeća prema krajnjim korisnicima. Uslužna orijentisanost može da se smatra konkurentskom prednošću na zahtevnom turističkom tržištu. Ova studija se bavi ispitivanjem odnosa između uslužne orijentacije (UO), zadvoljstva poslom (ZP) i organizacione podrške (OP) među zaposlenima u turističkim agencijama Republike Srbije. Izvršeno je anketiranje zaposlenih u turističkima agencijama putem online upitnika. U anketi su učestvovale 94 osobe. Cilj ove studije je da se istraži nivo zavisnosti uslužne orijentacije zaposlenih, zadovoljstvo poslom i organizacione podrške. Takođe, istraživalo se da li ima značajnijih odstupanja merenih varijabli kod zaposlenih sa i bez turističkog obrazovanja. Rezultati su pokazali da zadovoljstvo poslom ima značajan uticaj na uslužnu orijentaciju. Uticaj organizacione podrške na uslužnu orijentaciju pokazao se kao manje značajna statistička varijabla. Zadovoljstvo poslom se, prema istraživanju, javlja kao posrednik između organizacione podrške i uslužne orijentacije. Takođe, ne postoji statistički značajna veza između merenih varijabli i obrazovanja vezano za turizam.

Ključne reči: uslužna orijentacija, zadovoljstvo poslom, organizaciona podrška, turističke agencije, turističko obrazovanje

JEL Classification: L83

\section{UVOD}

U poslovnom svetu gde vlada velika konkurentnost, ljudski potencijal predstavlja osnovnu snagu kompanije. Zaposleni u turizmu imaju značajnu ulogu kada je u pitanju pružanje kvalitetnih usluga i rešavanje problema, pogotovo kada je klijent nezadovoljan. S obzirom na to da zaposleni imaju

* Korespondencija: M. Marjanović, Prirodno-matematički fakultet, Univerzitet u Novom Sadu, Trg Dositeja Obradovića 3, 21102 Novi Sad, Republika Srbija; e-mail:milos.marjanovic@mail.com direktan kontakt sa klijentima, njihovo ponašanje direktno utiče na proces donošenja odluka kod klijenata, kao i na percepciju klijenata o kvalitetu pruženih usluga (Malhotra \& Mukherjee, 2004). Uslužna orijentacija predstavlja bitan element organizacije, koji je zaslužan za stvaranje uslova za podsticanje zaposlenih na rad. Zaposleni će, za uzvrat, pružati visokokvalitetne usluge. Uslužna orijentacija zaposlenih može biti glavni faktor konkurentnosti na tržištu. Ona je važan pokretač koji će napraviti razliku između konkurenata. Kada govorimo o pružanju kvalitetnih usluga i rešavanju problema, 
glavnu ulogu imaju zaposleni, s obzirom na to da imaju direktan kontakt sa klijentima i konstantno su u interakciji sa njima. Njihovo ponašanje utiče na percepciju klijenata o kvalitetu pruženih usluga, kao i na donošenje odluka o eventualno novoj poseti istoj organizaciji ili kupovini istog proizvoda (Malhotra \& Mukherjee, 2004). R. Deshpandé, J. U. Farley and Jr. F. Webster (1993) ističu da zaposleni, koji su uslužno orijentisani, na prvom mestu stavljaju interes svojih klijenata, a potom svih drugih aktera (menadžera, vlasnika), kako bi razvili profitabilna preduzeća i osigurali dugoročan uspeh. Veliki broj istraživača se bavio temom uslužne orijentacije i mnogi od njih su došli do zaključka da postoji pozitivna veza između zadovoljstva kupaca i lojalnosti, kao i između zadovoljstva kupaca i težnje da se ponuda dobavljača preporuči drugim kupcima (Hartline \& Jones, 1996). Stvaranje lojalnog kupca jedan je od osnovnih ciljeva turističkih agencija. Lojalni kupac proističe iz uslužne orijentisanosti prodavca usluga. S toga je važno da menadžment preduzeća konstantno radi na prepoznavanju uslova koji utiču na svakog pojedinca, kako bi se on uslužno orijentisao prema klijentima i doprineo pozitivnom poslovanju kompanije (Lee, Nam, Park \& Lee, 2006). Uslužna orijentacija je jedan od ključnih faktora prilikom stvaranja superiorne vrednosti za kupca. Mnoga istraživanja su dokazala da su zadovoljstvo klijenta, lojalnost, povećanje profita i rast organizacije, direktno rezultat uslužne orijentisanosti kompanije. S druge strane, nedostatak inicijative za uspostavljanjem politike uslužne orijentisanosti, kao i nedostatak merenja i upravljanja uslužnom orijentacijom zaposlenih, može smanjiti dugoročne organizacione performanse (Lytle, Hom \& Mokwa, 1998).

Uslužna orijentacija se može definisati kao dodatni napor zaposlenih usmeren prema samoj organizaciji, ili prema klijentima (Bettencourt \& Brown, 1997). Veliki broj istraživanja se bavilo preduslovima za uslužnu orijentisanost. Značajan uticaj na uslužnu orijentisanost zaposlenih imaju zadovoljstvo poslom (Netemeyer, Boles, McKee \& McMurrian, 1997), organizaciona podrška (Spreitzer, 1995; Lytle et al, 1998), obuka (Lux, Jex \& Hansen, 1996), kao i sistem nagrađivanja (Lytle et al, 1998).
Predmet istraživanja u ovom radu je nivo zadovoljstva poslom, uslužne orijentacije i organizacione podrške u turističkim agencijama u Republici Srbiji (RS).

Cilj ove studije je formulisanje i empirijsko testiranje integrisanog modela međusobnih odnosa i uticaja uslužne orijentacije, zadovoljstva poslom i organizacione podrške.

Na osnovu toga, postavljeno je nekoliko hipoteza koje će biti testirane. Za prikupljanje podataka, korišćen je anketni upitnik koji je distribuiran putem interneta. Ciljna grupa u istraživanju jesu zaposleni $u$ turističkim agencijama $\mathrm{u}$ RS, bez obzira na poziciju u firmi.

Rad se sastoji iz nekoliko sekcija. Nakon Uvoda, daje se osvrt na istraživanja drugih autora o uslužnoj orijentaciji, zadovoljstva poslom, organizacione podrške i edukacije kroz pregled konsultovane literature. U sledećem delu će biti prikazane metode koje su korišćene prilikom ovog istraživanja i diskutovaće se o dobijenim rezultatima. Za sam kraj, daće se zaključna razmatranja.

\section{USLUŽNA ORIJENTACIJA}

Koncept uslužne orijentacije (UO) može se posmatrati na dva nivoa. Prvi nivo predstavlja organizacioni nivo, a drugi jeste individualni nivo. Organizacioni nivo orijentacije je usmeren na ono što menadžment organizacije smatra značajnim prilikom isporuke usluga visokog kvaliteta. Individualni nivo orijentacije se odnosi na uslužnu orijentaciju samog zaposlenog, koja je, prema njegovom mišljenju, važna za isporuku visokokvalitetnih usluga (Saura, Contrí, Taulet \& Velázquez, 2005). Jedan od najvažnijih činioca koji utiče na kvalitet pružene usluge u uslužnoj delatnosti jeste uslužna orijentacija zaposlenih (Petrović \& Marković, 2012). Ona ima ključnu ulogu za percepciju kvaliteta usluge i nivoa zadovoljstva klijenata (Sergeant \& Frenkel, 2000). Rad u turizmu, odnosno, rad u turističkim agencijama zahteva visok nivo interakcije sa potrošačima. $S$ toga, razumevanje koncepta uslužne orijentacije treba da ima važnu ulogu u poslovanju uslužnih preduzeća. U literaturi 
se, osim uslužne orijentacije zaposlenih, javlja terimin uslužne orijentacije organizacije, koja može da se predstavi kao ukupna klima organizacije, ili kao percepcije, verovanja i mišljenja svih zaposlenih (Lytle et al, 1998).

Ne postoji jedinstvena definicija uslužne orijentacije. Brojni teoretičari su na svoj način definisali uslužnu orijentaciju. Neki autori je definišu kao težnju zaposlenih da zadovolje potrebe svojih klijenata, ili kao želju zaposlenih da svoje klijente usluže na jedan koristan, kooperativan i ljubazan način (Brown, Mowen, Donava \& Licata, 2002). Mnoge studije su potvrdile da su klijentima važniji dostupnost i ljubaznost osoblja od stručnosti i tehnike organizacije (Dienhart, Gregoire, Downey \& Knight, 1992). Uslužna orijentacija može da se posmatra kao poslovni resurs (Zablah, Franke, Brown \& Bartholomew, 2012). Uslužno orijentisani zaposleni neće samo pružiti uslugu u okviru svoje nadležnosti, već će se potruditi da pruže dodatni kvalitet (na primer, informisati klijenta o dodatnim sadržajima na destinaciji, predložiti aranžman skladan odnosu cene i kvaliteta, izneti neko svoje lično ili tuđe iskustvo sa destinacije, ukazati na nedostatke aranžmana). Ovakvo ponašanje će, svakako, imati pozitivan uticaj na klijenta, a klijent će smatrati da je dobio extra uslugu, osetiće bliskost sa zaposlenim i sa agencijom, i to će uticati na njegovu percepciju kvaliteta usluge (Lee, Nam, Park \& Lee, 2006). Veliki broj istraživanja ukazuju na to da su klijentu bitniji ljubaznost, pristupačnost i otvorena komunikacija sa zaposlenima nego njegove kompetencije i organizacija posla (Čerović, Raičević, Todosijević i Tomka, 2002).

\section{ZADOVOLJSTVO POSLOM}

Veliki broj teoretičara danas smatra da zadovoljstvo poslom (ZP) može snažno uticati na celokupno poslovanje kompanije. Zadovoljstvo poslom je značajan pokazatelj dobrog poslovanja i blagostanja organizacije. To, dalje, implicira da zaposleni koji su zadovoljni, ređe napuštaju kolektiv. Zadovoljstvo poslom je jedno od najčešće istraživanih fenomena iz oblasti menadžmenta. Brojni autori su se bavili istraživanjem elemenata koji utiču na zadovoljstvo poslom. Pokazalo se da visok nivo zadovoljstva poslom uslovljava povećanje performansi i posvećenosti poslu, dok nizak nivo može izazvati smanjenje motivacije (Locke, 1976; Brown \& Peterson, 1993). Postoji veći broj definicija zadovoljstva poslom, a najčešće pominjanu je dao A. Locke (1976), koji kaže da je zadovoljstvo poslom pozitivna emocionalna reakcija zaposlenog, koja dolazi od njegovih radnih obaveza ili iskustva. Zadovoljstvo poslom se može definisati kao pozitivna ili negativna osećanja zaposlenog $\mathrm{u}$ vezi sa svojim poslom (Odom, Boxx \& Dunn, 1990). M. Hartline and O. Farrell (1996) ističu da je zadovoljstvo poslom zaposlenih u jednoj organizaciji bitno, jer utiče na kvalitet pružene usluge.

Osnovni zadatak rukovodioca jeste da konstantno održava i povećava zadovoljstvo poslom svojih zaposlenih, kako bi postigao pozitivne poslovne rezultate, s jedne strane, i kako bi konstantno imao zadovoljne klijente, s druge strane (Rogers, Clow \& Kash, 1994). Zadovoljstvo poslom ima uticaj na lojalnost zaposlenih (Williams \& Hazer, 1986) i na uslužnu orijentisanost (Hoffman \& Ingram, 1992). Neki autori su pokazali da zadovoljstvo poslom pozitivno deluje na radni učinak (Birnbaum \& Sommers, 1993). Što je radnik zadovoljniji, to će se više truditi oko svog učinka.

S toga, na osnovu navedenog, možemo da postavimo hipotezu:

H1: Zadovoljstvo poslom ima pozitivan uticaj na uslužnu orijentaciju.

\section{ORGANIZACIONA PODRŠKA}

Organizaciona podrška (OP) može se definisati kao stepen podrške i razumevanja koje osoba spoznaje od strane svog nadređenog. U fokusu je lider koji daje smernice svojim zaposlenima, odnosi se prema njima sa poštovanjem i smatra vrednim njihov doprinos poslovanju organizacije (Netemeyer et al, 1997). Neki autori definišu organizacionu podršku kao odobravanje zaposlenima da samostalno donose odluke prilikom svakodnevnog usluživanja klijenata. 
Organizaciona podrška je bitna prilikom pružanja usluga koje su heterogene i potrebno ih je oblikovati prema zahtevima klijenata. Zaposleni imaju potpunu slobodu da prilagode uslugu potrebama klijenata (Jha \& Nair, 2008). R. Brymer (1991) smatra da organizaciona podrška podrazumeva volju menadžera da pruži više slobode zaposlenima na radnom mestu. Dobar lider pruža podršku svojim zaposlenim tako što im olakšava put do njihovih ciljeva i time povećava njihovo zadovoljstvo poslom, a sve u cilju povećanja produktivnosti i postizanja ciljeva preduzeća (Brown \& Petterson, 1993). Neki autori u prvi plan stavljaju lidera kao nosioca organizacione podrške (Webster, 1988). S obzirom na to da je turizam uslužna delatnost, i da su zaposleni često u kontaktu sa klijentima, organizaciona podrška je neophodna jer je zaposlenima potrebno da $\mathrm{u}$ trenutku reše sve probleme, kako bi kupac bio zadovoljan (Hartline \& Ferrel, 1996). B. Shimko (1994) kaže da se organizaciona podrška može manifestovati kao sloboda zaposlenih da zaobilaze standardne radne procedure, a sve u cilju zadovoljenja potreba klijenata.

Organizaciona podrška ima višestruke efekte. Podrška zaposlenima povećava samopoštovanje i jača lojalnost prema organizaciji (Lee, Park \& Park, 1997) i povećava zadovoljstvo poslom (Spreitzer, Kizilos \& Nason, 1997). Osim što utiče na zadovoljstvo poslom i na lojanost zaposlenih, organizaciona podrška utiče i na radni učinak (Lee et al, 2006).

Shodno navedenom, možemo da postavimo drugu i treću hipotezu:

H2: Organizaciona podrška pozitivno utiče na zadovoljstvo poslom.

H3: Organizaciona podrška ima direktan uticaj na uslužnu orijentaciju.

\section{EDUKACIJA}

Kvalifikovani ljudski resursi imaju veliki značaj za produktivnost jedne kompanije. Pogotovo je ovo značajno ukoliko je njihovo obrazovanje vezano za oblast poslovanja kompanije. P. Barron (2008) navodi da je edukacija u uslužnoj delatnosti, a u turizmu, pre svega, jedan od faktora koji će u budućnosti imati presudnu ulogu na kvalitet pružene usluge. U uslužnoj delatnosti je teško naći i zadržati visoko kvalifikovane radnike koji će biti u mogućnosti da pruže usluge visokog kvaliteta sadašnjim i budućim klijentima. Zbog toga, edukacija ima važnu ulogu u budućem razvoju ovog servisnog sektora. V. Stefanović i Ž. Gligorijević (2010) navode da je edukacija u turizmu bitna, jer bez kontinuirane edukacije nema ni kontinuiranog ekonomskog prosperiteta. A. Lillo, A. Ramon i M. Sevilla (2007) navode da su količina znanja i veštine koje poseduje svaki pojedinac, glavni elementi ljudskog kapitala. Isti autori smatraju da kompetencije pojedinca zavise od nivoa ulaganja $\mathrm{u}$ formalno obrazovanje i jačanje praktičnog znanja radnim iskustvom.

U radu će biti ispitano da li postoje statistički značajne razlike u stepenu zadovoljstva poslom i stavovima o organizacionoj podršci i uslužnoj orijentaciji između zaposlenih koji imaju turističko obrazovanje i onih koji nemaju. U tom kontekstu, formuliše se četvrta hipoteza:

H4: Između zaposlenih koji poseduju turističko obrazovanje i onih koji ga ne poseduju, postoji razlika u stepenu zadovoljstva poslom i stavovima o organizacionoj podršci i uslužnoj orijentaciji.

\section{METODOLOGIJA}

Podaci za ovo istraživanje prikupljeni su od zaposlenih $\mathrm{u}$ turističkim agencijama u RS. Za dostavljanje anketnog upitnika, korišćena je poslovna baza podataka organizatora turističkih putovanja Euroturs. Upitnik je distribuiran software-om za komuniciranje sa partnerima. Upitnik je prosleđen organizatorima putovanja i posrednicima u prodaji aranžmana (subagentima). Poslat je na 380 e-mail adresa, od čega su 94 osobe učestvovale u anketi.

Primenom strukturalnog upitnika, izvršeno je kvantitativno merenje kojim su obuhvaćene tvrdnje 
koje se odnose na zadovoljstvo poslom, uslužnu orijentaciju i organizacionu podršku. Za ovaj upitnik korišćena je Likertova skala, koja se sastoji od 5 nivoa slaganja, gde je 1 - uopšte se ne slažem, 2 - ne slažem se, 3 - nemam mišljenje, 4 - slažem se i 5 - potpuno se slažem.

Za merenje zadovoljstva poslom, korišćene su varijable prilagođene iz istraživanja W. G. Kim, J. K. Leonga and Y. K. Lee (2005). Za merenje uslužne orijentacije prilagođen je upitnik iz istraživanja R. Dienhart et al (1992) i W. G. Kim et al (2005). Organizaciona podrška merena je upitnikom koji je konstruisao G. Spreitzer (1995), koja je prilagođena ovom istraživanju. Formiranju ovog anketnog upitnika, prethodila je analiza radova koji su obrađivali ove varijable.

Upitnik se sastoji iz 4 dela. Prvi deo obuhvata varijable koje se odnose na socio-demografske karakteristike ispitanika (pol, starost, stepen obrazovanja, itd.). U drugom delu, mereno je zadovoljstvo poslom, u trećem delu su se pitanja odnosila na uslužnu orijentaciju, a u poslednjem delu je merena organizaciona podrška.

Obrada podataka izvršena je uz pomoć statističkog software-a SPSS 25.0. Za analizu je korišćena deskriptivna statistika, regresiona analiza i T-test za dva nezavisna uzorka. Deskriptivna statistika je primenjena prilikom prikazivanja socio-demografskih karakteristika ispitanika. Regresiona analiza je primenjena za predviđanje uticaja nezavisnih varijabli zadovoljstva poslom i organizacione podrške na uslužnu orijentaciju. T-testom, za dva nezavisna uzorka, merena je potencijalna razlika između pola i obrazovanja vezanog za turizam. Kronbahov alfa test upotrebljen je radi testiranja pouzdanosti (interne konzistencije) svakog mernog instrumenta u upitniku, odnosno, grupe pitanja koja se koristi za ocenjivanje iste dimenzije (u ovom slučaju zadovoljstva poslom, uslužne orijentacije i organizacione podrške).

\section{REZULTATI}

Analizirajući podatke, došlo se do rezultata da je mnogo veći procenat učešća imala ženska populacija sa $80,85 \%$, a da su manje od jedne petine ispitanika muškarci, odnosno, svega 19,15\%. Oko trećine ispitanika je u tridesetim godinama, dok je 30,83\% ispitanika mlađe od 31 godine. Što se tiče stepena obrazovanja, 19,15\% ispitanika je sa srednjom školom, $58,51 \%$ je sa višom ili visokom školom, a 22,34\% sa masterom/magistraturom. Kod 65,96\% ispitanika je obrazovanje vezano za turizam. Među učesnicima istraživanja, 35,11\% imaju iskustvo u turizmu do 5 godina, a 21,27\% ispitanika ima preko 20 godina iskustva rada u turizmu (Tabela 1 ).

Tabela 1 Socio-demografske karakteristike ispitanika

\begin{tabular}{|c|c|c|}
\hline Varijabla & Broj & $\begin{array}{c}\text { Procenat } \\
\%\end{array}$ \\
\hline \multicolumn{3}{|l|}{ Pol } \\
\hline Muški & 18 & 19,15 \\
\hline Ženski & 76 & 80,85 \\
\hline \multicolumn{3}{|l|}{ Godine starosti } \\
\hline 20 i manje & 3 & 3,18 \\
\hline od 21 do 30 & 26 & 27,65 \\
\hline od 31 do 40 & 31 & 32,97 \\
\hline od 41 do 50 & 17 & 18,1 \\
\hline 51 i više & 17 & 18,1 \\
\hline \multicolumn{3}{|l|}{ Stepen obrazovanja } \\
\hline Srednja škola & 18 & 19,15 \\
\hline Viša ili visoka škola & 55 & 58,51 \\
\hline Master/magistar & 21 & 22,34 \\
\hline \multicolumn{3}{|c|}{ Obrazovanje vezano za turizam } \\
\hline $\mathrm{Da}$ & 62 & 65,96 \\
\hline $\mathrm{Ne}$ & 32 & 34,04 \\
\hline \multicolumn{3}{|c|}{ Godine radnog iskustva u turizmu } \\
\hline od 1 do 5 & 33 & 35,11 \\
\hline od 6 do 10 & 18 & 19,15 \\
\hline od 11 do 20 & 23 & 24,47 \\
\hline 20 i više & 20 & 21,27 \\
\hline
\end{tabular}

Izvor: Autor

U Tabeli 2 prikazane su srednje vrednosti, standardna devijacija i koeficijent korelacije za sve tri merene varijable. Može se videti da uslužna orijentacija 
Tabela 2 Cronbach alpha's, srednje vrednosti, standardna devijacija i koeficijent korelacije

\begin{tabular}{|c|c|c|c|c|c|c|c|}
\hline Varijable & $\begin{array}{l}\text { Cronbach } \\
\text { alpha's }\end{array}$ & Stavke & Srednja & St. dev. & \multicolumn{3}{|c|}{ Koeficijenti korelacije } \\
\hline Zadovoljstvo poslom & ,906 & 7 & 3,87 & ,74117 & $\begin{array}{l}\text { Zadovoljstvo } \\
\text { poslom }\end{array}$ & $\begin{array}{l}\text { Uslužna } \\
\text { orijentacija }\end{array}$ & $\begin{array}{c}\text { Organizaciona } \\
\text { podrška }\end{array}$ \\
\hline Uslužna orijentacija & 696 & 3 & 4,19 & 65529 &, $618^{* *}$ & & \\
\hline $\begin{array}{l}\text { Organizaciona } \\
\text { podrška }\end{array}$ & ,711 & 6 & 3,81 &, 59704 &, $498^{* *}$ &, $437^{* *}$ & \\
\hline
\end{tabular}

Napomena: **Korelacija je značajna na nivou 0,01

Izvor: Autor

i zadovoljstvo poslom imaju jači stepen linearne zavisnosti $\left(\mathrm{r}=, 618^{* *}\right)$, u odnosu na umereni stepen linearne zavisnosti između zadovoljstva poslom i organizacione podrške $\left(\mathrm{r}=, 498^{* *}\right)$ i uslužne orijentacije i organizacione podrške $\left(\mathrm{r}=, 437^{* *}\right)$.

Dobijeni rezultati pokazuju visok nivo statističke značajnosti, odnosno, visok nivo organizacione podrške prati visok nivo zadovoljstva poslom. Jednostrukom linearnom regresijom, testiran je uticaj organizacione podrške na zadovoljstvo poslom (Tabela 3). Rezultati pokazuju da postoji statistički značajan uticaj $($ sig $=0,000)$ i da je uticaj oblika:

$$
\mathrm{ZP}=1,712+0,567^{*} \mathrm{OP}
$$

Ovaj predikcioni model objašnjava 20,8\% $\left(\mathrm{R}^{2}=0,208\right)$ varijanse zadovoljstva poslom.
Rezultati ukazuju na to da zadovoljstvo poslom ima značajan uticaj na uslužnu orijentaciju i da uvođenje ove varijable $\mathrm{u}$ regresioni model čini uticaj organizacione podrške od strane nadređenog neznačajnim. To znači da je zadovoljstvo poslom medijator između uslužne orijentacije i podrške nadređenog.

Jednostrukom linearnom regresijom testiran je uticaj samo organizacione podrške na uslužnu orijentaciju. Rezultati pokazuju da postoji statistički značajan uticaj (sig =0,000) i da je uticaj oblika:

$$
U O=2,547+0,431^{*} O P
$$

Ovaj predikcioni model objašanjava $15,4 \%\left(\mathrm{R}^{2}=0,154\right)$ varijanse uslužne orijentacije.

\begin{tabular}{|c|c|c|c|c|c|c|c|}
\hline \multirow{2}{*}{ Model } & \multicolumn{2}{|c|}{ Nestandardizovani koeficijent } & \multirow{2}{*}{$\begin{array}{c}\text { Standardizovani } \\
\text { Koeficijent } \\
\text { Beta } \\
\end{array}$} & \multirow{2}{*}{$\mathrm{t}$} & \multirow{2}{*}{ Značajnost } & \multirow{2}{*}{$\mathrm{R}^{2}$} & \multirow{2}{*}{$\begin{array}{c}\text { sig. } \mathrm{R}^{2} \\
\text { promena }\end{array}$} \\
\hline & $\mathrm{B}$ & Std. greška & & & & & \\
\hline 1 (konstanta) & 2,547 & ,416 & \multirow{2}{*}{393} & 6,129 & ,000 & \multirow{2}{*}{,154 } & \multirow{2}{*}{0,000} \\
\hline $\mathrm{OP}$ & 431 & ,108 & & 4,007 &, 000 & & \\
\hline 2 (konstanta) & 1,741 &, 386 & \multirow{3}{*}{$\begin{array}{l}, 150 \\
, 533\end{array}$} & 4,511 & ,000 & \multirow{3}{*}{,379 } & \multirow{3}{*}{0,000} \\
\hline $\mathrm{OP}$ & ,164 & ,104 & & 1,575 &, 119 & & \\
\hline ZP & 471 & 084 & & 5,611 & ,000 & & \\
\hline
\end{tabular}

Tabela 3 Uticaj organizacione podrške, zadovoljstva poslom i uslužne orijentacije

a. Zavisna varijabla UO

Izvor: Autor 
Višestrukom linearnom regresijom, testiran je uticaj organizacione podrške i zadovoljstva poslom na uslužnu orijentaciju. Rezultati pokazuju da postoji statistički značajan uticaj $($ sig $=0,000)$ i da je uticaj oblika:

$$
U O=1,741+0,164^{*} \mathrm{OP}+0,471^{*} \mathrm{ZP}
$$

Ovaj predikcioni model objašanjava $37,9 \%\left(R^{2}=0,379\right)$ varijanse uslužne orijentacije. U odnosu na prvi model, drugi model donosi značajno poboljšanje (sig. $\mathrm{R}^{2}$ change $\left.=0,000\right)$. U drugom modelu, zadovoljstvo poslom je prediktor koji ima statistički značajnu predikcionu moć. Organizaciona podrška, za razliku od prvog modela, u drugom više nije prediktor sa statistički značajnom predikcionom moći. To ukazuje na koreliranost ova dva prediktora, sto je ranije i potvrđeno.

U Tabeli 4, T-testom za dva nezavisna uzoraka upoređeni su rezultati ispitivanja uslužne orijentacije, zadovoljstva poslom i organizacione podrške kod zaposlenih koji imaju obrazovanje iz oblasti turizma i onih koji imaju drugačiji obrazovni profil. Rezultati su pokazali da između grupa koje su turistički obrazovane ( $\mathrm{M}=3,81, \mathrm{M} 1=4,14, \mathrm{M} 2=3,81)$, odnosno, onih koji nisu (M=3,99, M1 =4,27, M2 = 3,82) ne postoji značajna statistička razlika.

U Tabeli 5 je T-testom za dva nezavisna uzorka prikazano kako se merene varijable manifestuju kod muške populacije, a kako kod ženske. Dobijeni rezultati pokazuju da ne postoji statistički značajna razlika između ispitanika muškog i ženskog pola.

\section{DISKUSIJA}

Cilj ove studije jeste formulisanje i empirijsko testiranje integrisanog modela međusobnih odnosa i uticaja uslužne orijentacije, zadovoljstva poslom i organizacione podrške. To je postignuto kroz analizu adekvatne literature i statističku obradu podataka.

Tabela 4 Poređenje merenih varijabli prema obrazovanju vezanom za turizam

\begin{tabular}{|c|c|c|c|c|c|c|}
\hline \multirow{2}{*}{$\begin{array}{l}\text { Turističko } \\
\text { obrazovanje }\end{array}$} & \multicolumn{2}{|c|}{ Zadovoljstvo poslom } & \multicolumn{2}{|c|}{ Uslužna orijentacija } & \multicolumn{2}{|c|}{ Organizaciona podrška } \\
\hline & $\begin{array}{c}\text { Srednja } \\
\text { vrednost }(M)\end{array}$ & $\mathrm{p}$ & $\begin{array}{c}\text { Srednja } \\
\text { vrednost }(M 1)\end{array}$ & $\mathrm{p}$ & $\begin{array}{c}\text { Srednja } \\
\text { vrednost }\left(M_{2}\right)\end{array}$ & $\mathrm{p}$ \\
\hline \multirow[t]{2}{*}{ DA } & 3,81 & & 4,14 & & 3,81 & \\
\hline & & ,284 & &, 364 & & ,897 \\
\hline NE & 3,99 & & 4,27 & & 3,82 & \\
\hline
\end{tabular}

T-test je značajan pri rezultatu $\mathrm{p}<, 05,{ }^{* *} \mathrm{p}<, 01,{ }^{* * *} \mathrm{p}<, 001$

Izvor: Autor

Tabela 5 Poređenje merenih varijabli prema polu

\begin{tabular}{c|cccccc}
\hline Pol ispitanika & \multicolumn{2}{|c}{$\begin{array}{c}\text { Zadovoljstvo poslom } \\
\text { Srednja }\end{array}$} & $\mathrm{p}$ & $\begin{array}{c}\text { Uslužna orijentacija } \\
\text { Srednja } \\
\text { vrednost }(\mathrm{M})\end{array}$ & $\mathrm{p}$ & \multicolumn{2}{c}{ Organizaciona podrška } \\
vušnost (M1) & $\mathrm{p}$ & $\begin{array}{c}\text { Srednja } \\
\text { vrednost (M2) }\end{array}$ & $\mathrm{p}$ \\
\hline Ženski & 4,01 &, 397 & 4,31 &, 423 & 3,96 &, 263 \\
\hline
\end{tabular}

T-test značajan pri rezultatu $\mathrm{p}<, 05,{ }^{* *} \mathrm{p}<, 01,{ }^{* * *} \mathrm{p}<, 001$

Izvor: Autor 
Rezultati analize su pokazali da zadovoljstvo poslom pozitivno utiče na uslužnu orijentaciju, čime je potvrđena hipoteza H1, odnosno, potvrđen je stav da postoji pozitivna veza između zadovoljstva poslom i uslužne orijentacije zaposlenog. K. Hoffman and T. Ingram (1992) opisuju osećaj zadovoljstva na radnom mestu kao rezultat ljubaznosti, senzibiliteta, brige za potrebe drugih, razumevanja, i mnogih drugih karakternih osobina za koje se veruje da su svojstvene uslužno orijentisanom osoblju. Zadovoljstvo poslom, takođe, utiče na maksimalno poštovanje klijenata od strane zaposlenih, naročito $u$ uslužnom sektoru. Shodno tome, istraživač ističe da zadovoljstvo poslom ima pozitivan uticaj na uslužnu orijentaciju. Visok nivo zadovoljstva poslom prati i visok nivo uslužne orijentacije. S toga je glavni zadatak menadžera preduzeća da u svom kolektivu ima visok nivo zadovoljstva poslom, što dalje vodi do pozitivnih ekonomskih rezultata, a to je osnovni cilj postojanja svakog preduzeća.

Dalji rezultati su pokazali da organizaciona podrška, odnosno, podrška nadređenih pozitivno utiče na zadovoljstvo poslom, što je u skladu sa istraživanjem G. Spreitzer et al (1997). Time je potvrđena hipoteza H2. Organizaciona podrška dovodi do povećanja samopoštovanja zaposlenog, što dalje utiče na zadovoljstvo poslom. Zadovoljan radnik će pružiti maksimum svojih mogućnosti da dostigne, ili prevaziđe, zahteve klijenata $u$ procesu pružanja usluga. Organizaciona podrška može da utiče na kreativnost i maštovitost radnika u turizmu prilikom kreiranja turističkih proizvoda, na osnovu iskustva iz direktne prodaje. Kada se u model istraživanja ubaci uslužna orijentacija, može se zaključiti da uticaj organizacione podrške nije značajan za uslužnu orijentisanost zaposlenih, čime se odbacuje hipoteza H3, da organizaciona podrška ima direktan uticaj na uslužnu orijentaciju. Ovde ulogu medijatora ima zadovoljstvo poslom, što dovodi do zaključka da organizaciona podrška ne mora direktno da utiče na uslužnu orijentaciju.

S obzirom na to da se danas sve više pažnje poklanja edukaciji radnika, testirana je veza između zaposlenih koji imaju turističko obrazovanje i onih koji nemaju turističko obrazovanje. Istraživanja su pokazala da ne postoje statistički značajne razlike između zaposlenih sa obrazovanjem vezanim za turizam i onih čije obrazovanje nije $\mathrm{u}$ vezi sa turizmom, već su razlike slučajne. Time se odbacuje hipoteza $\mathrm{H} 4$ da postoji razlika u merenim parametrima kod ispitanika sa turističkim obrazovanjem i onih bez turističkog obrazovanja. Svakako da je kontinuirana edukacija potrebna, jer je tržište na kome posluju turističke agencije heterogeno, usluge nisu standardizovane i tražnja se konstantno menja. Edukovani menadžeri mogu da predvide promene na tržištu i prilagode poslovnu politiku savremenim trendovima. U RS se u poslednje dve decenije intenzivnije otvaraju škole i smerovi vezani za turizam, tako da će obrazovani kadrovi biti na raspolaganju kompanijama, što dalje implicira lakše postizanje poslovne politike. Takođe, upoređivani su stavovi muške i ženske populacije koji se tiču uslužne orijentacije, zadovoljstva poslom i organizacione podrške. Došlo se do rezultata da ne postoji statistički značajna veza, a razlike su nasumične. Činjenica je da znatno više ženskih osoba radi u turističkoj delatnosti, ali kako je ovaj sektor sve zahtevniji, broj muškaraca je sve zastupljeniji.

\section{ZAKLJUČAK}

U ovom radu smo pokušali da proširimo znanje o uslužnoj orijentaciji zaposlenih, organizacionoj podršci i zadovoljstvu poslom u turističkim agencijama u Republici Srbiji. Testiran je međusobni uticaj ove tri varijable. Uz pomoć statističke obrade podataka, došlo se do rezultata koji potvrđuju, ili osporavaju ranije iznete tvrdnje autora. Rezultati su pokazali da najveći uticaj na uslužnu orijentaciju ima zadovoljstvo poslom. Ukoliko zaposleni nije u potpunosti zadovoljan na svom random mestu, on nije u stanju da pruža usluge visokog kvaliteta. S druge strane, kada se u model uvede i organizaciona podrška, može se doći do zaključka da ona indirektno utiče na uslužnu orijentisanost zaposlenih. Uticaj organizacione podrške na uslužnu orijentisanost se oseća kroz zadovoljstvo poslom. To znači da je zadovoljstvo poslom medijator između organizacione podrške i uslužne orijentacije. Ova studija, takođe, ističe važnost kontinuirane edukacije zaposlenih. 
Turizam je uslužna delatnost, u kojoj se tražnja brzo menja i trendovi treba da se konstantno prate kako bi se održao korak sa konkurencijom.

Rezultati ovog istraživanja mogu biti korisni menadžerima u turističkim agencijama, jer na osnovu ponašanja i stavova zaposlenih, mogu da poboljšaju standarde usluga. Kako podrška nadređenih dosta utiče na zadovoljstvo poslom, uloga menadžera bi bila takva da se potrude da stvore prijatnu radnu atmosferu u organizaciji, i da imaju otvoren odnos sa svojim radnicima. Efektivan sistem merenja performansi zaposlenih u nekoj kompaniji pruža mogućnost rukovodiocima da usklade performanse sa strategijom kompanije. Svaka kompanija je heterogen sistem koji zahteva jedinstveni model stvaranja okruženja u kome će do izražaja doći uslužna orijentisanost preduzeća. Potrebno je naći način kako pojedinca motivisati da bi pružio usluge najvišeg kvaliteta (Domanovic, 2013). Upravo je to misija svakog uslužno orijentisanog preduzeća.

Ovaj rad ima određena ograničenja koja mogu da posluže kao ideja za neko naredno istraživanje. Istraživanje je sprovedeno $u$ turističkim agencijama u RS. U anketi su učestvovali turističke agencije - organizatori putovanja i turističke agencije posrednici u prodaji aranžmana (subagent). Buduće istraživanje moglo bi da se bavi konkretnim tipom agencije, odnosno, da se sprovede istraživanje koje bi obuhvatilo samo organizatore putovanja ili samo subagente, s obzirom na to da postoje bitne razlike između ova dva tipa turističkih agencija. Takođe, mogli bi da se uporede rezultati testiranih kategorija za oba tipa turističkih agencija. Sledeće ograničenje je to što su u istraživanju učestvovali svi zaposleni, bez obzira na poziciju (služba prodaje, služba komercijale, vodička služba). Buduće istraživanje bi se moglo sprovesti prema radnim pozicijama, gde bi se uočile bitne razlike između pozicija koje imaju direktan kontakt sa potrošačima (služba prodaje, turistički vodiči i pratioci) i pozicija koje nemaju direktan kontakt sa klijentima (službe koje se bave kreiranjem proizvoda). Sledeće ograničenje jeste to što je istaživanje sprovedeno $\mathrm{u}$ agencijama na teritoriji RS. Buduća istraživanja mogla bi da se bave testiranjem istih varijabli u zemljama u okruženju, ili na turistički vodećim tržištima, a onda bi se mogli uporediti rezutati dobijenih istraživanjem. U ovom radu testirane su tri kategorije (uslužna orijentacija, zadovoljstvo poslom, i organizaciona podrška). Buduća istraživanja mogu da se baziraju na tome kako sistem nagrađivanja utiče na zadovljstvo poslom i lojalnost kompaniji, kako se zadovoljstvo poslom reflektuje na pružanje extra usluge klijentima, ili kako interna komunikacija utiče na uslužnu orijentaciju. Takođe, kao jedno od ograničenja možemo navesti mali uzorak (94 osobe su učestvovale u anketi). $\mathrm{Na}$ osnovu njihovih tvrdnji, ne možemo stvoriti generalnu sliku o stavovima zaposlenih u turističkim agencijama u Republici Srbiji.

\section{REFERENCE}

Barron, P. (2008). Education and talent management: Implications for the hospitality industry. International Journal of Contemporary Hospitality Management, 20(7), 730742. doi:10.1108/09596110810897583

Bettencourt, A., \& Brown, W. (1997). Contact employees: Relationship among workplace fairness, job satisfaction and prosocial service behavior. Journal of Retailing, 73(1), 3961. doi.org/10.1016/S0022-4359(97)90014-2

Birnbaum, D., \& Somers, M. (1993). Fitting job performance into turnover model: An examination of the form of the job performance - turnover relationship and path model. Journal of Management, 19(1), 1-11. doi.org/10.1016/01492063(93)90041-K

Brown, P., \& Peterson, A. (1993). Antecendents and consequences of salesperson job satisfaction: Meta-analysis and assessment of casual effects. Journal of Marketing Research, 30(1), 63-77. doi.org/10.1177/002224379303000106

Brown, J., Mowen, C., Donava, T., \& Licata, W. (2002). The customer orientation of service workers: Personality trait effects on self and supervisor performance ratings. Journal of Marketing Research, 39(1), 110-119. doi.org/10.1509/ jmkr.39.1.110.18928

Brymer, R. (1991). Employee empowerment: A guest-driven leadership strategy. Cornell Hospitality Quarterly, 32(1), 5868. doi:10.1177/001088049103200116 
Čerović, S., Raičević, B., Todosijević, B. i Tomka, D. (2002). Strategijski menadžment turističke privrede Srbije. Beograd, RS; Želnik.

Deshpandé, R., Farley, J. U., \& Webster, Jr. F. (1993). Corporate culture, customer orientation, and innovativeness in Japanese firms: A quadrate analysis. Journal of Marketing, 57(1), 23-37. doi:10.2307/1252055

Dienhart, R., Gregoire, B., Downey, G., \& Knight, K. (1992). Service orientation of restaurant employees. International Journal of Hospitality Management, 11(4), 331-346. doi. org/10.1016/0278-4319(92)90050-6

Domanovic, V. (2013). The effectiveness of the performance measurement in terms of contemporary business environment. Economic Horizons, 15(1), 33-46. doi:10.5937/ ekonhor1301031D

Hartline, M., \& Farrell, O. (1996). The management of customercontact service employees: An empirical investigation. Journal of Marketing, 60(4), 52-70. doi:10.2307/1251901

Hartline, M., \& Jones, K. (1996). Employee performance cues in a hotel service environment: Influence on perceived service quality, value, and word-of-mouth intentions. Journal of Business Research, 35(3), 207-215. doi.org/10.1016/01482963(95)00126-3

Hoffman, K., \& Ingram, T. (1992). Service provider job satisfaction and customer oriented performance. The Journal of Service Marketing, 6(2), 68-78. doi. org/10.1108/08876049210035872

Jha, S., \& Nair, S. (2008). Influence of locus of control, job characteristics and superior-Subordinate relationship on psychological empowerment. Journal of Management Research, 8(3), 147-161.

Kim, W. G., Leonga, J. K., \& Lee, Y. K. (2005). Effect of service orientation on job satisfaction, organizational commitment, and intention of leaving in a casual dining chain restaurant. International Journal of Hospitality Management, 24(2), 171-193. doi:10.1016/j.ijhm.2004.05.004

Lee, Y., Park, D., \& Park, Y. (1997). Perceived service orientation of customer contact service employees in the firms: The structural relationship between organizational values and employees"s attitudes. Asia Pacific Journal of Tourism Research, 4(1), 59-70.
Lee, Y., Nam, J., Park, D., \& Lee, K. (2006). What factors influence customer-oriented prosocial behavior of customer-contact employees? Journal of Service Marketing, 20(4), 251-264. doi:10.1108/08876040610674599

Lillo, A., Ramon, A., \& Sevilla, M. (2007). El capital humano como factor estrategico para la competitividad del sector turistico. Cuadernos de Turismo, 19, 47-69.

Locke, E. A. (1976). The nature and causes of job satisfaction. In M. D. Dunnette, (Ed.). Handbook of industrial and organizational psychology (pp. 1297-1343). Chicago, IL: Rand McNally.

Lux, D., Jex, S., \& Hansen, C. (1996). Factors influencing employee perceptions of customer service climate. Journal of market - focused management, 1(1), 65-86. doi:10.1007/ bf00129604

Lytle, S., Hom, W., \& Mokwa, P. (1998). SERV*OR: A managerial measure of organizational service-orientation. Journal of Retailing, 74(4), 455-489. doi.org/10.1016/S00224359(99)80104-3

Malhotra, N., \& Mukherjee, A. (2004). The relative influence of organizational commitment and job satisfaction on service quality of customer-contact employees in banking call centers. Journal of Service Marketing, 18(3), 162-174. doi:10.1108/08876040410536477

Netemeyer, G., Boles, S., McKee, O., \& McMurrian, R. (1997). An investigation into the antecendents of organizational citizenship behaviors in a personal selling context. Journal of Marketing, 61(3), 85-98. doi.org/10.2307/1251791

Odom, R., Boxx, W., \& Dunn, M. (1990). Organizational culture, commitment, satisfaction and cohesion. Public Productivity and Management Review, 14(2), 157-168. doi:10.2307/3380963

Petrović, D., \& Marković, J. (2012). Researching connection between service orientation and work satisfaction: A study of hotel employee. Turizam, 16(1), 29-39.

Rogers, J., Clow, K., \& Kash, T. (1994). Increasing job satisfaction of service personnel. Journal of Service Marketing, 8(1), 14-26. doi.org/10.1108/08876049410053267

Saura, I. G., Contrí, G. B., Taulet, A. C., \& Velázquez, B. M. (2005). Relationships among customer orientation, service orientation and job satisfaction in financial services. International Journal of Service Industry Management, 16(5), 497-525. doi:10.1108/09564230510625787 
Sergeant, A., \& Frenkel, S. (2000). When do customer contact employees satisfy customers? Journal of Service Research, 3(1), 18-34. doi.org/10.1177/109467050031002

Shimko, B. (1994). Breaking the rules for better service. The Cornell Hotel and Restaurant Administration Quarterly, 35(4), 18-22. doi.org/10.1177/001088049403500416

Spreitzer, G. (1995). Psychological empowerment in the workplace: Dimensions, measurement, and validation. Academy of Management Journal, 38(5), 1442-1465. doi. org $/ 10.5465 / 256865$

Spreitzer, G., Kizilos, M., \& Nason, S. (1997). A dimensional analysis of the relationsheep between psychological empowerment and effectiveness, satisfaction, and strain. Journal of Management, 23(5), 679-704. doi. org/10.1177/014920639702300504
Stefanović, V. i Gligorijević, Ž. (2010). Ekonomika turizma. Niš, RS: SVEN.

Webster, F. (1988). The rediscovery of the marketing concept. Busines Horisons, 31(3), 29-39. doi.org/10.1016/00076813(88)90006-7

Williams, L., \& Hazer, J. (1986). Antecendents and consequences of satisfaction and commitment in turnover models: A reanalysis using latent variable structural equation methods. Journal of Applied Psyhology, 71(2), 219231. doi.org/10.1037/0021-9010.71.2.219

Zablah, R., Franke, R., Brown, J., \& Bartholomew, E. (2012). How and when does customer orientation influence frontline employee job outcomes? A meta-analityc evaluation. Journal of Marketing, 76(3), 21-40. doi.org/10.1509/ jm.10.0231

Primljeno 24. septembra 2019, nakon revizije, prihvaćeno za publikovanje 13. aprila 2020. Elektronska verzija objavljena 24. aprila 2020.

Miloš Marjanović je student doktorskih studija na Prirodno-matematičkom fakultetu, Univerziteta u Novom Sadu, uža naučna oblast geonauka (turizam). Sfera interesovanja mu je motivacija u turizmu, geoturizam, regionalna geografija. 


\title{
SERVICE ORIENTATION OF THE EMPLOYEES IN SERBIA'S TOURISM AGENCIES
}

\author{
Milos Marjanovic \\ Faculty of Sciences, University of Novi Sad, Novi Sad, The Republic of Serbia
}

In a time of fierce competition in the tourist services market, it is very important to pay attention to businesses' service orientation towards end users. Service orientation can be considered as a competitive advantage on the demanding tourism market. In this study, the relationship between service orientation, job satisfaction and empowerment among the employees of Serbian travel agencies is examined. A survey was conducted through an online questionnaire. The survey included a total of 94 respondents. The study is aimed at investigating the connection between employee service orientation, job satisfaction and empowerment. The paper also investigates whether there are significant differences between the measured variables among the employees with and without tourism education. The results showed that job satisfaction had a significant impact on service orientation. The impact of empowerment on service orientation proved to be a less significant statistical variable. According to the research study, job satisfaction occurs as a mediator between empowerment and service orientation. Also, there is no statistically significant relationship between the measured variables and tourism-related education.

Keywords: service orientation, job satisfaction, empowerment, travel agencies, tourism education, prosocial service behavior

JEL Classification: L83 